Cahiers de recherches médiévales

\title{
glossa Aurelianensis est quae destruit textum
}

Medieval Rhetoric, Thomism and Humanism in Christine de Pizan's Critique of the Roman de la Rose

Earl Jeffrey Richards

\section{OpenEdition}

1 Journals

\section{Electronic version}

URL: https://journals.openedition.org/crm/1502

DOI: $10.4000 / \mathrm{crm} .1502$

ISSN: 1955-2424

\section{Publisher}

Honoré Champion

\section{Printed version}

Date of publication: 30 October 1998

Number of pages: $248-263$

ISSN: $1272-9752$

\section{Electronic reference}

Earl Jeffrey Richards, "glossa Aurelianensis est quae destruit textum", Cahiers de recherches médiévales [Online], 5 | 1998, Online since 01 October 2007, connection on 15 December 2022. URL: http:// journals.openedition.org/crm/1502 ; DOI: https://doi.org/10.4000/crm.1502

This text was automatically generated on 15 December 2022 .

All rights reserved 


\title{
glossa Aurelianensis est quae destruit textum
}

\author{
Medieval Rhetoric, Thomism and Humanism in Christine de Pizan's \\ Critique of the Roman de la Rose
}

Earl Jeffrey Richards

1 Christine de Pizan, writing in her last letter from the Quarrel on the Rose, addressed to Pierre Col, concludes by commenting laconically on Jean de Meung's specific misrepresentation of Nature. She associates Jean's rhetorical practice in Nature's speech with what she calls the proverb that «the glosses of Orléans destroy the text» (otherwise best known in Latin as glossa Aureliensis est quae destruit textum, a statement originally made by the jurist Franciscus Accursii ${ }^{1}$ ):

si as tres bien prouvey que maistre Jean de Meung, quant il tant perloit de exciter

l'œuvre de Nature, que il entendoit en mariage! Dieux, comment est ce bien prouvé!

Voire, come dist le proverbe commun des gloses d'Orliens, qui detruisent le texte. ${ }^{2}$

2 Although the first known source of the Latin version of the proverb here was Franciscus Accursii, it might be tempting, in light of the growing evidence that Christine was familiar with a considerable body of legal learning, to see in Christine's oblique reference to a French proverb a more profound reference to the body of legal commentary on the Corpus juris civilis. At this point, however, it is more prudent to stress that Christine notes the proverbial nature of the claim and does not herself connect it with Franciscus Accursii. Nevertheless, why does Christine connect Jean's recurrent and unfilled promise of a glose to his work with a glossa Aurelianensis, the fourteenth-century epitome of legalistic and rhetorical sophistry? The continuous and systematic subversion of referentiality in Jean's work ultimately, at least in Christine's view, destroys the text's meaning in the name of the text's form. Christine's claim captures in nuce her entire philosophy of literature itself, for she was combatting the rhetorization of literature for its own sake, divorced from an concern for society's morals. This procedure is typical of Jean's work where formal procedures engulf, cancer-like, the entire work itself and where meaning at best disappears and reappears like a Cheshire cat. 
Christine's statement might show that her dissatisfaction with the portrayal of Nature in the Rose stems from her adherence to the Ciceronian link between virtue and rhetoric, from the parallel influence of Thomist thought on her (in this case Aquinas' critique of Averroism) and from her belief in French universalism as a middle way between Jean's appropriation of the studium to France and Petrarch's division between italiani and barbari. Christine's universalism was not a gratuitous gesture, but a profound response to the literary nationalism, or proto-nationalism, of Jean, a nationalism founded on a heightened sense of lyrical subjectivity, ineffability, solipsism and rhetorical sophistry. Sadly, Christine renounced this universalism in the Ditié de Jeanne d'Arc, in which France assumes a privileged place in salvation history.

How can we reconstruct the influence of the various schools of medieval rhetoric on Christine? From the five-part division found in the prose letters of Christine de Pizan, we might infer that Christine was familiar with the ars dictaminis that had been perfected earlier in Bologna. ${ }^{3}$ In any event, her immediate source for adopting this fivepart division in her prose letters was most likely Bruentto Latini's Livre dou Tresor where this format is recommended in place of Cicero's six-part division ${ }^{4}$ and in place of Boncompagno's proposed three-part division. On the other hand, Christine's verse epistles, taking their cue from Petrarch's cultivation of the genre, point to an almost opposing tendency that actively cultivated the revival of Classical lore otherwise neglected by the Italian schools. This double and perhaps conflicting point of departure shows how difficult and how necessary it is to situate Christine within the rhetorical practices of her time.

I. Hortensia, Rhetoric and la cause des femmes

5 In order to determine the influence of late medieval rhetoric on Christine, we might begin with Le Livre de la Cité des Dames, II.36.2. Christine recounts the story of Hortensia, whose father, the rhetorician Quintus Hortensius- remembered in the title of the Ciceronian fragment Ad Hortensium, the work Augustine cites as instrumental to his conversion- insisted that his daughter be educated in rhetoric, a science which his daughter applied to defend the cause of women, la cause des femmes, or the res feminarum, as Boccaccio calls it in De claris mulieribus, Chapter 84 (and here we have the late 14th- and early 15th-century term for feminism):

N'estoit pas de celle oppinion Quintus Ortensius qui estoit a Romme grant rethoricien et souverain dicteur. Cellui ot une fille nommee Ortence que il moult ama pour la soubtilleté de son engin et lui fist apprendre letres et estudier en la dicte science de rethorique, dont elle tant en apprist que non pas tant seulement, ce dit Bocace, a son pere Ortencius par engin et vive memoire elle ressembla et en toute faconde mais aussi de bien prononcier et de toute ordre de parleure si bien que en riens il ne la passoit. Et au propos de ce qui est dit dessus du bien qui vient par femmes, le bien qui par ceste femme et par son savoir avint fu un nottable entre les autres, c'est assavoir que ou temps que Romme estoit gouvernee par iij. hommes, ceste Ortence prist a soutenir la cause des femmes et a demener ce que homme n'osoit entreprendre - c'estoit de certaines charges que on vouloit imposer sur elles et sur leur aournemens ou temps de la neccessité de Romme. Et de ceste femme tant estoit belle la eloquence que non pas moins voulentiers que son pere estoit ouye et gaigna sa cause."

6 The example of Hortensia shows us that Christine, following the aesthetics of Thomas Aquinas, linked the beauty of eloquence to its practical and epistemological effect on her hearers, or in Aquinas' formula in the Summa, pulchrum autem respicit vim 
cognoscitivam. ${ }^{6}$ Beauty is not ineffable in Aquinas but directly linked to consciousness. We will see that Aquinas' thought also shaped Christine's application of rhetoric.

While Christine could have followed and probably did follow Eustache Deschamps' recommendation in his Ballade 1367 that every bon rhetoricien should know the works of Valerius Maximus, Cicero, Livy, Seneca, John of Salisbury, Vergil and Socrates, in practice she was most heavily indebted to Isidore, Brunetto Latini and Petrarch. Her indebtedness to these writers gave her philosophy of rhetoric its particular and idiosyncratic stamp. The combination of Brunetto and Isidore in the Mutacion de Fortune, as shown by Suzanne Solente, needs to be explained by adding Petrarch to the list of Christine's rhetorical authorities.

By seeking to situate herself within a rhetorical tradition defined by Isidore of Seville's Etymologiae and by Brunetto Latini's Rettorica and Livres dou Tresor, Christine associated herself with the revival of Ciceronian rhetoric championed by Brunetto. Isidore was a practical compendium, with little direct connection to Cicero as such even though Book II of the Etymologiæ states that after its invention in Greece, rhetoric was translata in Latinum a Tullio videlicet, ${ }^{7}$ but Brunetto saw his rhetorical work squarely within a Ciceronian tradition. All medieval writers on rhetoric, with the exception of Boncompagno da Signa, paid enormous lip service to Cicero as the magister eloquentiae, to use the phrase of Geoffroi de Vinsauf. In practice, this tradition boiled down to a series of stylistic exercises, although in the 1140's Thierry de Chartres wrote a commentary on Cicero's De inventione, stressing the theme of the civilizing influence of letters. This largely formal and practical orientation left rhetoric open to sophistic abuses, and Christine, following Brunetto and Jean Gerson, and like Petrarch, saw rhetoric from a moralist perspective and assumed a clearly anti-sophistic position, which explains, in part, her critique of the Rose.

In response to the extreme anti-Ciceronian stance taken by Boncompagno (who had claimed rhetorica compilata per Tulliam Ciceronem iudicio studentium est cassata ${ }^{8}$ ), Christine incorporates elements of Petrarchan humanism into her works (specifically in her return to the auctores, in her scepticism toward «courtly» values, her incorporation of political subjects into her work, her use of allegory and in her imitation of a periodic, though not Ciceronian, style). By contrast, Jean radicalizes the rhetorical teachings of the French schools in a sophistic manner when he departs in a fundamentally antirational way from earlier philosophical allegory written under their influence. Jean's treatment of Nature exemplifies this departure. It is no coincidence that Christine's critique of Jean focuses, among other things, on the speech of Nature. Jean's deviation from the allegorical practices found in Alain de Lille's De planctu Naturae and Jean de Hanville's Architrenius corresponds to the separation of vernacular allegory from Biblical exegesis. Winthrop Wetherbee noted how Jean departs from Chartrian allegory in his elevation of sexual fulfillment as an end in itself as articulated in the speech of Nature. ${ }^{9}$ Yet this departure from Christian and Chartrian allegory was by no means inevitable or programmatic, as Christine's preface to Lavision, with its careful attention to traditional patristic allegoresis, shows.

10 Christine's expectation from allegory might be judged conservative or even reactionary if we take the Rose as the standard against which late medieval allegory must be measured. If we compare the allegory of the Rose to that of Dante's Commedia, as Christine did, Jean's allegory emerges as shallow and sophistic (consistent with the difference that she sees between sçavant and sage in Le Livre des Trois Vertus, p.150 and in 
Le livre de la paix, p.70). Unlike Jean, whose endless play foregrounds form at the expense of content, Christine drew a sharp distinction between poetic form and philosophical truth, as for example in Lavision, when she notes that «Aristote [...] impugna Thales et les autres poetes, non mie impugna en tant comme pouetes mais en tant que ilz semblent philosophes et sont hors de verité».10 Besides faulting his allegorical technique, Christine objects to Jean's anti-rationalism, his elevation of sexual pleasure as an end in itself (this sexual solipsism being the logical consequence of Jean's lyrical subjectivity), and his slander of women. These tendencies feed Jean's nationalism which in turn provoked Petrarch. Christine and Petrarch, in one sense, were disputing the same assumptions underlying Jean's poetic philosophy. Not only does Christine not accept Jean's sophistry, she will follow the example of Hortensia and plead la cause des femmes.

II. Christine, Isidore and le fondement des sciences et des ars liberaux

11 Prior to the composition of Le livre de la paix, Christine cites Aristotle as the primary authority in rhetorical questions, although the only explicit references to Aristotle's Rhetoric as such that I have found in Christine are in Le Livre du Corps de policie (pp. 62, 96). Aristotle is otherwise frequently invoked as the exemplum of great learning in L'Epistre d'Othea, Lavision, Le Livre de la Cité des Dames and Le livre des Trois Vertus. In addition to this superficial use of Aristotle, what authors influenced Christine's philosophy of rhetoric? We can look first to Isidore, whose work Christine knew both from excerpts and in its complete form and whose influence is not always explicit. In Book III, chapter 3 of her life of Charles V, Christine claims to be citing Augustine, whereas in fact she was actually quoting Isidore's text, as found in Thomas Hibernicus' compilation Manipulus Florum, on the origin of the word philosopher. Christine, however, must have had a complete text of Isidore when she incorporated extensive citations from the Etymologiae into the Mutacion de Fortune, completed somewhat earlier than the biography of Charles V.

In the Mutacion de Fortune (vv. 7937-7964) Christine translates almost verbatim Isidore's crucial differentiation between rhetoric and dialectic: rhetoric is like an open hand, and dialectic like a closed fist. ${ }^{11}$ Here Christine cites Varro, Isidore's source, rather than Isidore himself. Yet Isidore was not only a quarry of classical loci for Christine, but also an authority for the link between rhetoric and the liberal arts themselves. As she notes:

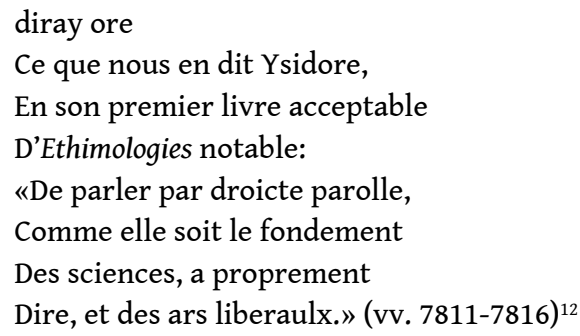

This rhetorical attitude dovetails nicely with the link between rhetoric and grammar eloquence and linguistic correctness- and reappears in the anecdote of Hortensia cited above in which eloquence is defined as the combination of bien prononcier and toute ordre de parleure. ${ }^{13}$

That Isidore was a constant source for Christine is further apparent in the crucial passage on antiphrasis cited near the beginning of the Cité des Dames to point out the deficiencies of the allegory of the Rose. ${ }^{14}$ Christine invokes antiphrasis without mentioning Isidore's name, but a rapid inspection of other rhetorical writers will show 
that Donatus and Isidore alone used the term. ${ }^{15}$ In criticizing the Rose, Christine specifically singles out its portrayal of marriage, the same topic that she had cited in her letter to Pierre Col in which this portrayal is associated with the gloses d'Orliens.

Moreover, Isidore is the likely source for the section in the Cité des Dames, III.1.2 which lists the names of the Virgin. This praise of the Virgin is reminiscent of the topos of nomina Christi, first explained by Isidore in Etymologiae VII.2: the section on the nomina Christi is followed by other chapters treating names of the apostles, the angels, and in VII.10 one finds a short passage on the names of the Virgin. The innumerable medieval hymns relating the names of the Virgin postdate Isidore, of course, and could just have easily inspired Christine, ${ }^{16}$ except that Petrarch adduces the topos of the nomina Christi as an argument for the theological nature of poetry, a contention that Christine also uses. Petrarch had observed: Parum abest quin dicam theolgiam esse poeticam de Deo: Christum modo leonem modo agnum modo vermem dici, qui nisi poeticum est? (Le Familiari, $\mathrm{X} 4,1),{ }^{17}$ whereas Christine uses the phrase pouetes theologisans twice in Lavision (p. 119). While her source for this terms could have been either Dante or Petrarch, or both, ${ }^{18}$ an affinity with Petrarch's Christian humanism is at least present.

III. Christine, Brunetto Latini and Cicero:

The Pursuit of Virtue

When Christine describes rhetoric in the fourth part of the Mutacion de Fortune (vv. 7977-8006), her description is for all intents and purposes a rhymed version closely following Brunetto's prose. This passage is the first positive reference to Cicero in Christine's works, marking a shift in her reception of the magister eloquentiae. When Christine cites «Tulles» here, she is quoting Brunetto's own excerpt of Cicero, a pattern followed as well in Le Livre de la paix. Brunetto's translation and his Livres dou Tresor had defended the Ciceronian tradition against Boncompagno's criticisms. Christine, in turn, gradually came to a more positive view of Cicero under the influence of Brunetto.

While Christine's belief in the political importance of rhetoric is ultimately Ciceronian in origin, until she cites actually Cicero's De rhetorica in Latin for the first time in Le livre de la paix, Cicero himself essentially remained for Christine more often than not an unregenerate misogynist. To add insult to injury, Christine's opponents in the debate over the Rose often cite Cicero. Jean de Montreuil, in his Letter 154, cites Cicero when he compares Christine to Leontium: «michi tamen audire visum est Leuntium grecam meretricem, ut refert Cicero, que «contra Theofrastum, philosophum tantum, scribere ausa fuit».» (Hicks, p.42) Christine never forgot the insult and she champions Leontium as a philosopher in the Cité des Dames, I.30.3, where Christine pointedly emphasizes Leontium's erudition AND purity in language clearly echoing Jean de Montreuil: «Et femmes de grant science te pourroie dire assez. Leonce, qui fu femme grecque, fu autresi si tres grant philosophe que elle osa par pures et vrayes raisons reprendre et redarguer le philosophe Teophraste qui en son temps tant estoit renommez» (p.160). By the same token, Pierre Col also cites Cicero three times in a very short space in his «Responce» (Hicks, p.101), while Jean Gerson cites Cicero only once in his Traité (p.82, from the De officis).

In the Cité des Dames, Christine makes a single and rather negative reference to Cicero consistent with the tone of the story of Leontium. In I.9.3, Christine asks: «Dame, selon que j'entens de vous, femme est moult noble chose, mais toutevoyes dit Tulles que homme ne doit servir nulle femme, et que cellui qui le fait s'aville, car nul ne doit servir plus bas de lui» (p.78). The response comes swiftly: «Cellui ou celle en qui plus a vertus 
est le plus hault, ne la haulteur ou abbaissement des gens ne gist mie es corps selon le sexe mais en la perfeccion des meurs et des vertus» (p.80). Le livre de la paix echoes this passage, except there Christine directly cites Cicero. Significant at this point is that Christine does not associate the connection between rhetoric and virtue with Cicero. In other words, the shift in Christine's use of Cicero comes somewhat later in her career. In the Livre du Corps de policie, Christine follows a practice of cluster quotations, where she first cites Aristotle or Seneca, and then Cicero, all on the same topic, so that it seems apparent that she was probably using Thomas Hibernicus' Manipulus Florum or some other anthology organized by topics. ${ }^{19}$

Nevertheless, by the time Christine wrote Le livre de la paix, she cites Cicero as the authority for the conjunction of virtue and rhetoric. The circle is complete: in the dedicatory letter to Isabeau de Bavière from her epistles on the Rose, Christine had made essentially the same point, «pour ce que telle vertu est trouvee en vostre noble entendement, est chose convenable que dictiéz de choses eslues vous soient presentéz» (Hicks, p.5). Now, in Chapter Four of Le livre de la paix, entitled «Cy commence a parler a l'ennortement de vertu a mon dit seigneur» (Willard, ed., p.63-64), she cites Cicero's De rhetorica, making the practical -and characteristically moralistic- link between virtue and rhetoric:

Sola virtus in sua potestate est; omnes bene vivendi raciones in virtute sunt colocande. Enim non multum potest obesse fortuna qui sibi firmius in virtute quae in casu presidium collocavit. Tulius, Libro ij Rethoricus qui Ars Nova appelatur.

Christine explains that virtue provides the only means of avoiding the vicissitudes of fortune:

Comme toutes choses ça jus soient falibles, seulle vertu, dist Tulles, est en la puissance d'elle meismes, c'est à entendre durable, et pour ce les raisons que on puet mectre pour bien vivre doivent estre assises en vertu, car certes fortune ne puet estre contraire à celuy qui plus s'afiche en vertu que es bien de fortune et d'aventure.

21 When Christine cites Cicero twice later on in this same chapter, she in fact is citing from Brunetto Latini's Tresor, II.ii, although she had quoted Cicero in Latin at the start: «Tulles dit: Il n'est plus amiable chose que la vertu,» and «Tulles dit: On doit eslire la tres meillor voie de vivre.» In other words, Christine explicitly combines Brunetto's translation of Cicero with Cicero's original, the logical culmination of her changing reception of Cicero.

IV. Christine and Petrarch: Is Cicero the authority for Latin superiority or for the preeminence of virtue?

Christine mentions Petrarch only once by name, in the Cité des Dames, and this single allusion led earlier scholars to discount Petrarch's influence on Christine, even though Mathilde Laigle, as early as 1912, pointed out that Christine's father must have known Petrarch in Venice during the period between May 1362 and $1365 .{ }^{20}$ Let us review the evidence for Christine's knowledge of Petrarch's works.

She cites Petrarch by name in the Cité des Dames, II.7.121, and she uses Petrarch's rather than Boccaccio's version of the Griseldis story in the Cité des Dames, II.50 (De oboedentia ac fide uxoria mythologia, included in Philippe de Mézières' Livre de la vertu du sacrement du mariage). In Le Livre des Trois Vertus, III, xi, she also alludes, without explicit reference, to Petrarch's I Trionfi (1374) as signaled by Charity Cannon Willard (p.218). In addition, other evidence for Petrarch's influence on Christine has been presented by 
Gilbert Ouy, Angus Kennedy, Lori Walters and myself. ${ }^{22}$ We must also consider the following potential links to Petrarch: the only model I know of for verse epistles was Petrarch's epistolae metricae; and as Lori Walters has shown, Christine's Cent Ballades are heavily influenced by Petrarch's own lyrics, which recalls Petrarch's influence on Gerson's bucolic play in verse. I suspect that if we re-examine Christine's «pastoral» poetry, we might begin to detect Petrarch's influence on Christine in a manner consistent with Petrarch's influence on Jean Gerson, as Gilbert Ouy has ascertained. A new picture also emerges when one also realizes that prior to Christine and Gerson, only Petrarch had criticized the Rose: while Petrarch attacked Jean de Meung's nationalism, Christine and Jean Gerson criticized Jean's anti-rationalism, which went hand in hand with his nationalism. Christine and Jean Gerson must have felt a certain Petrarchan legitimation when they launched their critique of Jean de Meung. If Gerson thought of himself as an «émule de Pétrarque,» to use Ouy's felicitous phrase, can we not transfer this designation to Christine as well? ${ }^{23}$

I wish to argue that the debate on the Rose constituted the beginning of a much larger literary quarrel conducted by humanists regarding the fate of the Latin studium. The first volley in the quarrel was a verse epistle written around 1340 by Petrarch to Guido Gonzaga in which Petrarch, citing the authority of Cicero, claimed that Italian eloquence (which included for him all Latin literature) surpassed that of all other languages, and he singled out the most popular vernacular work of his day, the Roman de la Rose, as proof of his point. ${ }^{24}$ In the same verse epistle, Petrarch goes on to argue that the works of Catullus, Ovid and Propertius -identified by their respective birthplaces- demonstrate the unchallenged superiority of Italian letters. Petrarch's selection of Catullus, Ovid and Propertius contrasts with Jean's invocation of Tibullus (v. 10478), Gallus, Catullus and Ovid (v. 10492), hardly a coincidental overlapping. Petrarch is, unfortunately, as adamant a literary nationalist as Jean, although Jean is never as blunt as Chrétien de Troyes about the French appropriation of the studium. ${ }^{25}$ Petrarch's judgment of the Rose and its reception leaves little doubt that he believed that contemporaries saw the Rose as pre-eminent proof of French literary superiority, a claim he refused to accept. Petrarch again cites Cicero in his Apologia as his authority for the unsurpassed nature of Italian eloquence. The passage from Cicero to which Petrarch alludes both in his letter to Guido Gonzaga and in his Apologia is the opening of the De finibus bonorum et malorum, in which Cicero defends his writing in Latin rather than Greek. Dante had alluded to the same passage as well in Convivio, I.xi.12-14, so it is clear that Cicero's defense of Latin against Greek in Dante's hands becomes a defense of the vernacular against gramatica and in Petrarch's a defense of Italian as the successor of Latin. ${ }^{26}$

Petrarch's nationalism hardly squares with his better known moralism. ${ }^{27}$ Yet we must face the difficult questions raised by Petrarch's literary nationalism, since it was in one sense directly provoked by Jean's claims. When Christine compares Dante and Jean, she did so in full cognizance of the nationalist values championed by Jean. Thus the Quarrel of the Rose is actually part of a greater pan-European discussion -lasting well into the sixteenth century- summarized in Petrarch's famous remark oratores et poetae extra Italiam non querantur. Christine's response to Jean and to Petrarch shows how her philosophy of rhetoric attempted to preserve the cosmopolitan context of literary creation. Both Petrarch and Jean are alike in their nationalism, both assign their 
respective nations transcendental values at variance with the nominal ideal of Christian universalism.

V. Aquinas, the Rose and Christine

Christine's remarks on the gloses d'Orliens focus on Jean's portrayal of Nature. As Matthieu-Maxime Gorce long ago noted:

Nous savons que les condamnations de 1270 et 1277 visent les diverses erreurs des gentils professées à Paris. Or, on pouvait trouver le genre d'erreurs qui vient d'être signalé, dans le Contra gentiles où, près de vingt ans plus tôt, Thomas d'Aquin signale déjà les mêmes idées à Paris. [...] J'avais signalé [...] que l'écrit De amore sive de Deo amoris devait avoir pour doctrine cette théologie sexuelle visée par saint Thomas dans ce passage de la Somme contre les gentils et par les propositions ci-dessus de la condamnation de 1277. J'avais même eu la hardiesse de faire des idées de l'écrit $D e$ amore, la source, de caractère universitaire, du Roman de la rose de Jean de Meung. ${ }^{28}$

In one of the more fiery passages of Europäische Literatuar und Lateinisches Mittelalter, Ernst Robert Curtius follows Gorce in making this connection. ${ }^{29}$ I do not wish to exaggerate Jean's alleged Averroism, since recent Rose scholarship has tended to emphasize Jean's orthodoxy ${ }^{30}$ In reviewing the scholarship on the question, however, the issue is in fact a narrow one. Gorce never overstates his evidence, he never argues for Jean's full-blown adherence to Averroism, only that certain propositions of the condemnation of 1277 seem to single out prominent aspects of the Rose. Christine's attacks on the portrayal of Nature in Jean de Meung may be further evidence for the influence of Thomas Aquinas on her thought.

In light of the growing evidence for Christine's knowledge of Aquinas, it is useful to revive the old Averroist question. Liliane Dulac and Christine Reno recently demonstrated how conversant Christine in Lavision was with Thomas Aquinas' commentary on the Metaphysics of Aristotle (1272). ${ }^{31}$ Christine's incorporation of Aquinas' commentary on Aristotle's Metaphysics in the life of Charles V is also well known. In two separate essays I have shown how Christine's depiction of her own birth in the Mutacion de Fortune was influenced by Aquinas' discussion de producione mulieris in the Summa and that Christine was profoundly familiar with Aquinas' De ente et essentia (1256). ${ }^{32}$ Now, Aquinas' attacks on Averroism in Contra gentiles, III.136, laid the groundwork for the two decrees against Averroism in the 1270's which coincide with the completion of Jean de Meung's portion of the Rose (since Félix Lecoy established 1268 as a terminus a quo and 1278 as a terminus ad quem, these decrees would confirm his dating). On balance, therefore, I would suggest that Christine had these anti-Averroist writings of Aquinas in mind when she criticized Jean's portrayal of Nature. Christine's knowledge of these works might help explain the prominence of arguments about Nature and women at the beginning of the Cité des Dames. There may even be a vague allusion to the Contra gentiles at the beginning of the Cité des Dames where Christine, besides spending a great deal of time talking about how Nature created men and women, comments on the love between them. Aquinas speaks of the viri et mulieris conjunctio which seems to be echoed in the passage «car il n'est ou monde nul si grant ne si fort lian comme est cellui de la grant amour que Nature par voulenté de Dieu met entre homme et femme» (p. 66).

VI. Cicero in the Roman de la Rose and Jean de Meung's Contamination of Literary Culture

Ciceronian rhetoric is conspicuously absent in the Roman de la Rose, with one telling exception. Guillaume's opening alludes to the Somnium Scipionis from Cicero's De re 
publica, Liber VI as it had been preserved in the fourth-century commentary of Macrobius but Guillaume never even mentions Cicero's name. ${ }^{33}$ While Cicero's De amicitia is an important source for Ami's speech, the only mention of Cicero's rhetoric is an ironic reference in -of all places again- the speech of Nature, more properly Jean de Meung's reworking of Alain de Lille's De planctu Naturae, (what Jean Gerson called corrumpuement estraitte du grant Alain, [Hicks, p.80]) before her confession to Genius. Genius' response to Nature, given before he hears Nature's «confession,» comprises in extraordinarily compact and virulent form one of the most misogynist parts of the entire Rose.

When Christine specifically speaks of Nature in her letter to Pierre Col, she must have had in mind this passage ${ }^{34}$ with its direct reference to Cicero ( «si con Tulles le nous remembre/ou livre de sa Rethorique,/qui mout est sciance autantique»). Jean's allusion to Cicero's Rhetoric might explain why Christine during the early part of her career viewed Cicero as a misogynist.

The catalogue of the stereotypical charges in Nature's speech -that women are changeable, fickle, credulous, avaricious, indiscreet- is answered systematically by Christine in the Cité des Dames, and Christine's reply is no mere inversion of the terms of misogynist discourse, no simple dialectical transformation of negative stereotypes into positive ones. For Christine differences between women and men must dissolve in the presence of a larger human dignity which literary art must lay open. Christine took her cue from Jean de Meung, to be sure, but escaped the dialectic of gender difference so central to his misogyny.

We must face the fact that the Rose celebrates a hardly innocent ideal of misogynist literary culture founded on a heightened narcissism or lyrical subjectivity that relegates women at best to passivity. The very popularity of the Rose is a sad testimony to the fact that late medieval literary culture was fatally tainted with misogyny. Jean was so busy proclaiming the establishment of the studium in France -exemplified without irony by his person- that he deliberately neglected specific moralist aspects of Latin literary culture, narrowing it to lyric. If Jean de Meung had chosen as his subject another marginalized group like Jews instead of women, would we still be prepared to accept the glowing accounts of his work that modern critics recurrently employ? We must reopen the debate on the Rose by taking Christine's and Jean Gerson's criticisms more seriously than hitherto. The very tainted nature of the Rose explains why Italian authors, including Brunetto Latini, Dante and Petrarch, pointedly refrain from mentioning the Rose, though they all certainly had read it. From Christine's perspective, the connection between misogyny and Jean's abuse of rhetoric was clear with the rape at the end of the Rose the logical conclusion of this attempt to silence and objectify woman.

VII. The Destruction of the Text in the Roman de la Rose

What ultimately is so disturbing, so subversive about the Rose is its much praised hermeneutical indeterminancy -its Cheshire cat quality. It is not simply, as David Hult describes the situation with Gui de Mori's redaction of the Rose that the Jean «leaves himself open to an infinite number of future textual variants, all of which will depend on the viewpoint of each new reader ${ }^{35}$ By equating absolute textual indeterminacy with the relativizing implications arising from the different reader responses, Hult probably overstates a central tenet of reception aesthetics and ignores the fact that Jean is not consistently ironic throughout his part of the Rose. No, the Rose, for all its 
flights into ineffability, is not entirely devoid of stable meaning, ${ }^{36}$ as Jean's hardly modest self-election as the successor of the Latin lyric love poets demonstrates. The most prominent and consistently stable meanings that otherwise also emerge are Jean's nationalism, his lyrical subjectivity, and his abuse of women in the name of rhetorical form.

Christine and Jean Gerson objected to the essentially subversive nature of the Rose itself, nothing more and nothing less. The Rose connects lyrical subjectivity and textual ineffability with cultural nationalism, and this combination will prove to be absolutely explosive, especially if we consider how modern literary nationalism follows the same pattern as Jean de Meung.

VIII. Translatio Studii, Nihilism and Cultural Nationalism

The link between irrationality (founded on lyrical subjectivity) and cultural nationalism found in the Rose is also a very modern phenomenon. Julien Benda spoke of the transition from la culture to ma culture in La Trahison des Clercs. The connection between heightened subjectivity- and the resulting nihilism- and nationalism was first examined by Ernst Robert Curtius in his Maurice Barrès und die geistigen Grundlagen des französischen Nationalismus (1921). Curtius traces the programmatic development between Barrès' early culte du moi and his subsequent nationalism, how the nation becomes a transcendental moi, and how a fundamental nihilism underlies both the culte $d u$ moi and literary nationalism. The inability to believe or to affirm anything forces the poet first to cultivate his own narcissism, and when this becomes, as it must, boring, to transfer this narcissism to a greater corporate entity. A comparable connection stands at the heart of the Quarrel of the Rose, for Jean's claim that studium now resided in France was tantamount to a nationalist (and again, very modern) dissolution of the republic of letters. Christine's invocation of the glossa Aurelianensis quae destruit textum shows that she saw that Jean's sophistic play led at length to nihilism as well.

The discussion of translatio studii in the Rose and in other medieval French authors has often risked turning into an endorsement, rather than a critical assessment, of the topos itself. Christine's use of the topos had nothing in common with Jean's nationalism. ${ }^{37}$ It is time for critics of the Rose to stop ignoring or endorsing the cultural nationalism underlying the Rose, a facet of its «meaning» that remained fairly stable. ${ }^{38}$ Is the meaning of the translatio studii topos at the midpoint of the Rose a proleptic justification of «French» literature or of a «national» literature at the expense of all other literatures? Brunetto's and Dante's silence regarding their indebtedness to the Rose surely stems in part from their literary cosmopolitanism. Dante speaks of «us, for whom the world is our homeland just as for fish the sea» (nos cui mundus est patria velut piscibus cequor), whereas Jean de Meung wants to be a big fish in a small French pond.

IX. Christine's Universalism as a Response to Jean de Meung and Petrarch

37 Christine wrestled with the question of national allegiance throughout her career, in part as a response to the competing nationalist claims of Jean de Meung and Petrarch. She addressed this problem most directly in Le Livre de la Corps de policie, Part Three, Chapter Two, entitled «De la difference de pluseurs peuples.» The entire passage is fascinating because Christine appeals first to the universalism of literary culture and then to the specific needs of her French audience:

Pour ce que l'abitacion ou nous sommes residens est es parties de France, non obstant que escriptures de livres par especial que touchent meurs et doctrince doie estre generale et touchant les habitans de toutes contrees, comme livres soient 
ventilés et portés en diverses places et regions, nous souffira nostre parole et doctrine au peuple françois, laquele dite parole et doctrine pourra semblablement servir generalment en toutes aultres regions qui bien et en son droit entendement la vouldra prendre pour bon exemple. (p.169) universalist perspective into a potentially virulent form of nationalism. Joan of Arc, for Christine, should first drive the English from France and then unite all Christendom in a crusade against Islam. Suddenly the French assume a special role in salvation history, following the model of Guibert de Nogent's Gesta Dei per Francos, the medieval precursor of the belief in Gott mit uns. Perhaps an embittered Christine succumbed to the influence of Petrarch after all and wished to assign to France a spiritual prerogative in Christendom. Étienne Gilson put the situation in the following terms:

Ce nationalisme de la culture ouvre une ère nouvelle et annonce la fin de l'universalisme médiéval, qui n'était que celui de l'Église catholique même. Dante était sur l'autre versant [...] le monde est notre patrie, proclamait-il, comme la mer est celle des poissons, même si nous avons bu l'eau de l'Arno avant d'avoir des dents. A ce nos autem cui mundus est patria velut piscibus aequor s'oppose exactement la division pétrarquiste du monde en Italiens et en barbares, avec toutes les conséquences qu'elle comporte."

We live with these same consequences today. The question remains whether we are prepared to oppose this continuing division in the Republic of Letters. Christine was generally sensitive to the universal requirements of literary culture, which is why she employed women as an allegory of the people of God in her City of Ladies, women representing men and women in the pilgrimage of the Church Militant on its way to the Heavenly Jerusalem. Yet the pull of a universal culture faded with the rise of Joan of Arc, and the growing political necessity to legitimize a national culture, even on the grounds that it afforded a model to all, marks an important step toward national particularism. It is thus one of the ironies of Christine's career that she ended up endorsing the kind of cultural nationalism so much at the heart of the Roman de la Rose, the nationalism which dovetails so neatly with the very male narcissicism that Christine had so carefully criticized at the beginning of her career.

\section{NOTES}

1.On Franciscus Accursii, see Gérard Giordanengro, «Studium Aurelianense, Les écoles et l'université de droit (XIII ${ }^{\mathrm{e}} \mathrm{XIV}{ }^{\mathrm{e}}$ siècles) d'après des recherches récentes des historiens néerlandais», Perspectives médiévales, Société de langue et de littérature médiévales d'oc et d'oil, nº18 (juin 1992), pp. 8-21, especially pp. 12, 20; and F. P. W. Soetermeer, «Recherches sur Franciscus Accursii, Ses Casus Digesti Novi et sa répétition sur la loi 
Cum pro eo (C. 7,47 un.)», Tijdschrift voor rechtsgeschiedenis 51 (1983), pp. 3-49. My thanks to Eric Hicks for calling my attention to Giordanengro's research.

2.Christine de Pizan et al., Le débat sur le Roman de la Rose, ed. Eric Hicks (Paris: Champion, 1977), p. 144. Hicks identifies the proverbial source in his note on this passage on p. 227.

3.See my article, "Seulette a part -'The Little Lady on the Sidelines' Takes Up Her Pen», Dear Sister, Medieval Women and the Epistolary Genre, ed. Karen Cherewatuk and Ulrike Wiethaus (Philadelphia: University of Pennsylvania Press, 1993), pp. 139-170.

4.James Murphy, Rhetoric in the Middle Ages, A History of Rhetorical Theory from Saint Augustine to the Renaissance (Berkeley: University of California Press, 1974), p. 255, «Boncompango attempted one major dictaminal reform, which failed utterly. First in the Palma and then in the Rhetorica novissima, he attempted to set up a system of threepart letters instead of five».

5.Christine de Pizan, La città delle dame, a cura di Patrizia Caraffi, Edizione di Earl Jeffrey Richards (Milan: Luni Edizione, 1997), pp. 314, 316.

6.See the discussion of Aquinas' aesthetics in Edgar de Bruyne, Études d'esthétique médiévale, (Bruges: de Tempel, 1946), v. III, pp. 278-346.

7.Peter Marshall in his studies of the medieval reception of Isidore shows that Isidore's reception was never seen in connection with Cicero, despite the claim made by Murphy that Isidore was squarely in the Ciceronian tradition. See the very useful introduction to his edition of Isidorus Hispalensis, Etymologiae II, Les Belles Lettres (Paris, 1983).

8.Boncompagno da Signa, Rhetorica novissima, ed. Augusto Gaudenzio, Scripta Anecdota Antiquissimorum Glossatorum, v. 2 of Biblioteca Iuridica Medii Aevi (Bologna, 1892), p. 252. 9.Platonism and Poetry in the Twelfth Century, The Literary Influence of the School of Chartres (Princeton: Princeton University Press, 1972), p. 257: «Unlike the heroes of Alain and Jean de Hanville, the Lover of the Roman remains willfully ignorant his plight to the end. [...] Sexual fulfillment, not as a metaphor for rational self-awareness, but as an end in itself, is the Lover's goal, and it is hard to see his success as affirming anything more positive. There is evidently something amiss in the world of the Roman which has no clear precedent in the allegories of the Chartrians.»

10.Christine de Pizan, L'Avision-Christine, ed. Mary Louis Towner (Washington, D.C.: The Catholic University of America, 1932), p. 121.

11.Isidore, Entymologice, II.xxiii: «Dialecticam et Rhetoricam Varro, in novem disciplarum libris, tali similitudine definivit: 'Dialectica et Rhetorica est quod in manu hominis pugnus adstrictus, et palma distensa: illa verba contrahens, ista distendens.' Dialectica siquidem ad disserendas res acutior: Rhetorica illa quae nititur docenda facundior. Illa ad scholas nonnumquam venit: ista iugiter procedit in forum. Illa requirit rarissimos studiosos: haec frequenter et populos.», cited from Isidori Hispalensis Episcopi Etymolgiarum sive Originum Libri XX, ed. W.M. Lindsay (Oxford: Clarendon, 1911)

12.Le Livre de la Mutacion de Fortune, ed. Suzanne Solente (Paris: Picard, 1959-1966).

13.The entire text from Le Livre de la Mutacion de Fortune, vv. 8007-8014, 8023-8028, reads:

Ysidore, ou premier chapitre

D'Ethimologies, le titre

De Rethorique volt escripre, Dist que «Pour la coppie d'eloquence, Ordre de droicte consequance Neccessaire en toutes similes 
Questions, plaines ou soubtilles [...]

Et est Rethorique conjoincte

A l'art de Gramatique et jointe,

Car, quant Gramaire apprenons,

Science de parler prenons,

Et Rethorique si apprent

A prononcier ce qu'on comprent.»

14.La città delle dame, p. 48: «Et des poetes dont tu parles, ne scez tu pas bien que ilz ont parlé en plusieurs choses en maniere de fable et se veulent aucunefois entendre au contraire de ce que leurs diz demonstrent? Et les peut on prendre par une figure de grammaire qui se nomme antifrasis qui s'entent, si comme tu scez, si comme on diroit tel est mauvais, c'est a dire que il est bon, aussi a l'opposite. Si te conseille que tu faces ton prouffit de leurs dis et que l'entendes ainsi quelque fust leur entente es lieux ou ilz blasment les femmes. Et par aventure que cellui d'homme qui se nomme Matheolus en son livre l'entendi ainsi.»

15.Isidore, Etymologice, I.xxxvii.24: «Antiphrasis est sermo e contrario intellegendus.» See also Marilynn Desmond, Reading Dido, Gender, Textuality and the Medieval Dido (Minneapolis: University of Minnesota Press, 1994), p. 200: «Christine no doubt based this passage on the discussion of antiphrasis in the section on grammar from the Etymologiae of Isidore of Seville.» 16.Christine, as Maureen Curnow noted (The «Livre de la Cité des Dames de Christine de Pizan", A Critical Édition, Ph.D. Dissertation, Vanderbilt University, 1975, p. 1117), uses many of the same epithets for the Virgin in her Oroison Nostre Dame.

17.See Ernst Robert Curtius, Europäische Literatur und Lateinische Mittelalter 10. Auflage (Berne: Francke, 1984), p. 233, n. 1, and his essay, «Nomina Christi» in Mélanges de Ghellinck, II, 1951, p. 1029, reprinted in Gesammelte Aufsätze zur romanischen Philologie (Berne: Francke, 1960), pp. 373-375, «Bei Petrarch dienen die nomina Christi als Stütze für die These, daß Poesie eine Art Theologie sei.»

18.See my discussion of poets' and theologians' allegory in "Christine de Pizan and Sacred History» in The City of Scholars, ed. Margarete Zimmermann and Dina De Rentiis (Berlin: de Gruyter, 1994), pp. 19-21.

19.Christine de Pizan, Le Livre du Corps de policie, ed. Robert H. Lucas (Geneva: Droz, 1967), p. 45, «Et dit Tulles ou second livre Des Offices il n'est plus mauvais vice en prince ou en ceulx qui gouvernent la chose publique que avarice»; p. 65: «et ceste [vieillesce] cy loue Tulles en son livre De Vieillesce»; p. 66 «Et dit Tulles a ce propos que vieillesse est plus forte et plus courageuse que jeunesse»; p. 72: «Pericles [fut homme] moult vertueux selon que tesmoigne Tulles en son livre Des Offices»; p. 74: «selon ce que dit Tulles»; p. 101: «Ce dit Tulles que a peine treuve l'en homme qui aprés grans labeurs vertueux ne desire gloire et honneur pour partie de son guerdon.»

20.Mathilde Laigle, Le Livre des Trois Vertus de Christine de Pisan et son milieu historique et littéraire (Paris: Champion, 1912), p. 79.

21. La città delle dame, p. 240, 242, «O! Dieux scet quans filz de grans seigneurs et de riches hommes desirent la mort de leurs parens pour avoir leurs terres et leur avoir. Et de ce bien dit voir Petrarc qui dist, 'o fol homme, tu desires avoir enfans mais tu ne peus avoir nulz si mortieulx ennemis. Car, se tu es povre, ilz seront tanez de toy et desireront ta mort pour en est deschargez, et se tu es riche, ilz ne la desireront pas moins pour avoir le tien'.» Curnow identifies this passage as a general summary of ideas on the joys and sorrows of children from Petrarch's De remediis utriusque Fortunae 
(p. 1082) and concludes that this single reference demonstrates Christine's lack of familiarity with Petrarch's works.

22.Gilbert Ouy, «Gerson, émule de Pétrarque, Le Pastorem Carmen, Poème de jeunesse de Gerson, et la renaissance de l'églogue en France à la fin du XIV ${ }^{\mathrm{e}}$ siècle», Romania 88 (1967), pp. 175-231; and «La dialectique des rapports intellectuels franco-italiens et l'humanisme en France au XIV et XV ${ }^{e}$ siècles», Rapporti culturali ed economici fra Italia e Francia nei secoli dal XIV al XVI (Rome, 1979); Angus J. Kennedy, «A Note on Christine de Pizan and Petrarch», Celestinesca 11 (1987), 24; Richards, «Christine de Pizan, the Conventions of Courtly Diction, and Italian Humanism,» Reinterpreting Christine de Pizan, ed. E.J. Richards with Joan Williamson, Nadia Margolis and Christine Reno (Athens: University of Georgia Press, 1992), pp. 250-272; Lori Walters, «Chivalry and the (En)Gendered Poetic Self, Petrarchan Models in the Cent Balades,» The City of Scholars, 43-66.

23.Christine was also very familiar with many of Gerson's sermons: Livre des Trois Vertus (I.iv/106, II.iv/18, II.xii/1, III.x/12), Le Livre du Corps de policie, (Vivat rex; see Lucas ed., p. XLIII, n.)

24.The text of the epistle (Poesi minori del Petrarca [Milan, 1831], v. 2, pp. 342-45) reads in part:

Itala quam reliquias superet facundia linguas, Vir praestans, Graiam praeter, (si fama sequenda est Et Cicero) nullam excipio, brevis iste libellus Testis erit, clara eloquio quem Gallia caelo Attolitque favens, summisque aequare laborat Silicet hic vulgo recitat sua somnia Gallus.

[ «O excellent man, how Italian eloquence conquers all other languages besides Greek (if one follows fame, and Cicero). I make no exception and this little book of yours will be a witness which France, famous for eloquence, has favored and borne to heaven and strives to make equal to the greatest works, that is, where a Frenchman recites his dreams in the vernacular.»]

25.Cligès, ed. A. Micha, vv. 31-37:

Puis vint chevalerie a Rome

Et de la clergie la some,

Qui or est an France venue.

Dex doint qu'ele i soit maintenue

Et que li leus li abelisse

Tant que ja mes de France n'isse

L'enors qui s'i est arestee.

26.Cicero was also important to Petrarch, and thus by extension, potentially important to Christine, because, to put the argument in a very compressed form, Augustine saw his conversion as having begun in his own reading of Cicero. Petrarch, who always carried a copy of Augustine's Confessions with him, adopted Augustine's attitude toward Cicero and rejected the anti-Ciceronian position of Bolognese rhetoricians. Thus, Christine could potentially have been influenced- though probably indirectly- by this Petrarchan attitude. Augustine's explanation comes in Confessiones, III.4, (S. Aureli Augustini Confessionum Libri XIII, ed. Martin Skutella [1934], editionem correctiorem curaverunt Heiko Jürgen et Wiebke Schaub [Stuttgart: Teubner, 1969], p. 40-41): «inter hos ego inbecilla tunc aetate discebam libros eloquentiae, in qua eminere cupiebam fine damnabili et ventoso per guadia vanitatis humanae, et usitato iam discendi ordine perveneram 
in librum cuiusdam Ciceronis, cuius linguam fere omnes mirantur, pectus non ita. sed liber ille ipsius exhortationiem conent ad philosophiam et vocatur Hortensius. ille vero liber mutavit affectum meum et ad te ipsum, domine, mutavit preces meas et vota ac desideria mea fecit alia.» Cf. Peter Brown, Augustine of Hippo, A Biography (Berkeley: University of California Press, 1969), pp. 40-41 and M. Testard, St. Augustin et Cicéron (Paris, 1958), v.1, pp. 20-35. 27.Nicholas Mann, «Petrarch's Role as Moralist in Fifteenth-Century France», Humanism in France at the End of the Middle Ages and in the Early Renaissance, ed. A.H.T. Levi (Manchester: Manchester University Press, 1969), pp. 6-28.

28.Matthieu-Maxime Gorce, L'essor de la pensée au Moyen Âge, Albert le Grand - Thomas d'Aquin (Paris, 1933; Geneva, 1978), pp. 174-175.

29.Curtius, op. cit., p. 135, «Die Göttin Natura ist zur Handlangerin geiler Promiskuität geworden, ihre Regelung des Liebeslebens ins Obszöne travestiert. Die unbefangen spielende Erotik des lateinischen Humanismus, das stürmische Anrennen schweifender Jugend gegen die christliche Moral ist auf die Stufe einer sexuellen Aufklärung hinabgesunken, die aus gelehrtem Flitter und spießbürgerlicher Lüsternheit eine gepfefferte Hausmannskost braut. Wie war das möglich? Es entsprach der Libertinage einer Epoche, die das Erbe antiker Schönheit in die Scheidemünze akademischer Begriffsklauberei umgewechselt hatte.»

30.See Karl August Ott, Der Rosenroman, Erträge der Forschung, Bd. 145 (Darmstadt: Wissenschaftliche Buchgesellschaft, 1980), pp. 101-103.

31.Liliane Dulac and Christine Reno, «L'humanisme vers 1400, Essai d'exploration à partir d'un cas marginal: Christine de Pizan, Traductrice de Thomas d'Aquin», Pratiques de la culture écrite en France au XV'siècle (Louvain-la-Neuve: Brepols, 1995), pp. 161-178. See also Liliane Dulac and Christine Reno, «Traduction et adaptation dans l'AdvisionCristine de Christine de Pizan», Traduction et adaptation en France à la fin du Moyen Âge et à la Renaissance, ed. Charles Brucker (Paris: Champion, 1997), pp. 121-131.

32. «In Search of a Feminist Patrology: Christine de Pizan and the glorieux dotteurs of the Church", Une femme de Lettres au Moyen Âges, Études autour de Christine de Pizan, ed. Liliane Dulac and Bernard Ribémont (Orléans: Paradigme, 1995), pp. 281-295; and «Rejecting Essentialism and Gendered Writing: The Case of Christine de Pizan» in Gender and Text in the Later Middle Ages, hrsg. Jane Chance (Gainesville: University Press of Florida, 1996), pp. 96-131.

33.In fact, before Macrobius even relates the dream, he comments that Cicero's intention in the Somnium Scipionis was to target men who hid their ignorance of the truth under a show of learning, genus hominum veri ignarum sub peritiae ostentatione, a formula meant to refer to the Epicureans and their criticism of Platonic myths. In one sense, the peritiae ostentatio of Jean's part show his affinity to the genus hominum veri ignarum: «Ac priusquam somnii verba consulimus, enodandum nobis est, a quo genere hominum Tullius memoret vel irrisam Platonis fabulam, vel ne sibi idem eveniat non vereri. nec enim his verbis vult inperitum vulgus intellegi, sed genus hominum veri ignarum sub peritiae ostentatione, quippe quos et legisse talia et ad reprehendendum constaret animatos.» (M. Tullius Cicero, De re publica librorum sex quae manserunt septimum recognovit, ed. $\mathrm{K}$. Ziegler, M. Tulli Ciceronis Scripta quae manserunt omnia, Fasc. 39, Bibliotheca Teubneriana [Leipzig: BSB B.G. Teubner, 1969], p. 125: «But before we consider the words of the dream, we ought to explain for what kind of men Cicero was speaking about this mocking fable of Plato, or even whether one should fear lest the same happen to one. For with these words he did not mean the uneducated masses but the kind of men [who hide their] ignorance of the truth under the show of learning, indeed, 
as all are agreed, those inclined to reproach these things upon reading them.») See also William Harris Stahl's useful Introduction and notes to his translation of Macrobius, Commentary on the Dream of Scipio (New York: Columbia University Press, 1952).

34. The entire passage in question (Le Roman de la Rose, ed. Félix Lecoy [Paris: Champion, 1965-1970], vv. 16155-16168) is as follows:

Zeusys neïs par son biau paindre ne porroit a tel fourme ataindre, qui, por fere l'ymage ou tample, de $\cdot v \cdot$ puceles fist example, les plus beles que l'en pot querre et trover en toute la terre, qui devant lui se sunt tenues tout en estant tretoutes nues, por soi prendre garde en chascune s'il trovoit nul defaut en l'une, ou fust seur cors ou fust seur membre, si con Tulles le nous remembre ou livre de sa Rethorique, qui mout est sciance autantique. 35.David Hult, Self-fulfilling Prophecies, Readership and Authority in the First «Roman de la Rose» (Cambridge: Cambridge University Press, 1986), p. 89.

36.It was hardly received in a social or in a political vacuum -for example, Alexander Murray, writing in Reason and Society in the Middle Ages (Oxford: Oxford University Press, 1978) points out similarities between Guillaume Peyraut's critique of heriditary nobility and Jean de Meung's position on nobility, and concludes: «These depreciations of nobility were no mere 'asides' from Jean de Meung; nor are the allegorical figures in his poem consistent enough to suggest these were not the poet's own private opinions. They were deeply felt. The mere mention of nobles was often enough to touch off a burst of Jean's egalitarian indignation» (p. 277)

37.In 1977, writing in her Stanford Ph.D. dissertation, Nadia Margolis spoke of Christine's use of this topos in her Poetics of History, An Analysis of Christine de Pizan's "Livre de la Mutacion de Fortune», (p. 226). Liliane Dulac and Christine Reno point out the presence of the topos in Lavision, op. cit. p. 172. Lori Walters in «Translatio Studii: Christine de Pizan's Self-Portrayal in Two Lyric Poems and in the Livre de la Mutacion de Fortune,» also discusses the topos especially with reference to Christine's lyric. These four scholars do not argue in favor of Christine's nationalism, indeed, the second Athens invoked in Lavision (p. 76, 109) is not France at all.

38.Ernst Robert Curtius warned against the circularity of all such arguments in his 1949 essay on «Antike Rhetorik und Vergleichende Literaturwissenschaft» (reprinted in Gesammelte Aufsätze, p. 19) and his warning bears repeating: «Der Glaube an einen invariablen Nationalcharakter impliziert aber außerdem einen circulus vitiosus und ist schon aus diesem Grunde nicht annehmbar. Woher kennen wir den Charakter einer Nation? Wir lesen ihn ab aus ihren geistigen Schöpfungen. Das 'Wesen' einer Nation wird aus der Literatur abgeleitet und in begriffliche Formeln gebracht. Dann werden die Begriffe hypostasiert und in dieser Form zur Interpretation der Literatur verwendet. Man holt den Nationalcharakter aus einer Schachtel heraus, in der man ihn vorher versteckt hatte. Für das Verständnis ist damit nichts geleistet.» 39.Étienne Gilson, La philosophie au moyen âge (Paris, 1947), pp. 727-28. 